\title{
Relationship between milk fat and protein contents and cheese yield
}

\author{
Isabelle VERDIER-METZ ${ }^{\mathrm{a} *}$, Jean-Baptiste COULON $^{\mathrm{b}}$, \\ Philippe PRADEL ${ }^{\mathrm{c}}$
}

\author{
a Laboratoire de Recherches Fromagères, INRA, 36 rue de Salers, 15000 Aurillac, France \\ ${ }^{\mathrm{b}}$ Unité de Recherche sur les Herbivores, INRA, Theix, 63122 Saint-Genès-Champanelle, France \\ ${ }^{\mathrm{c}}$ Domaine de la Borie, INRA, 15330 Marcenat, France
}

(Received 4 January 2001; accepted 3 October 2001)

\begin{abstract}
The relation between the useful material content (protein+fat content) of milk and cheese yield was analyzed on 189 manufactures of pressed uncooked cheeses. These manufactures were realized under controlled conditions in the same experimental cheese dairy, within the framework of eight different experiments, from milks of high hygienic quality (cows free of clinical mastitis) partially skimmed so as to have a fat/protein ratio of 1.15 . The fat+protein content of manufactured milks varied from 55 to $85 \mathrm{~g} \cdot \mathrm{kg}^{-1}$. The relation between fat+protein content and cheese yield was linear for this wide range of variation. Fat+protein content accounted for $77 \%$ of fresh yield and $87 \%$ of dry matter yield variability. Once the effect of fat and protein contents have been taken into account, other milk parameters ( $\mathrm{pH}, \kappa$-casein variants) may have a significant effect on cheese yield, but in a marginal way.
\end{abstract}

milk / fat and protein contents / cheese yield

Résumé - Effet de la teneur en matière utile du lait sur le rendement fromager. La relation entre la teneur en matière utile (taux protéique + taux butyreux) du lait et le rendement fromager a été analysée sur 189 fabrications de fromages à pâte pressée non-cuite. Ces fabrications ont été réalisées en conditions contrôlées dans une même fromagerie expérimentale dans le cadre de 8 essais différents, à partir de laits de haute qualité hygiénique (issus de vaches indemnes de mammites cliniques) partiellement écrémés de manière à avoir un rapport $\mathrm{TB} / \mathrm{TP}$ de 1.15 . La teneur en matière utile des laits mis en fabrication a varié de 55 à $85 \mathrm{~g} \cdot \mathrm{kg}^{-1}$. Sur cette large plage de variation, la relation entre la teneur en matière utile et le rendement fromager a été linéaire. La teneur en matière utile du lait explique à elle seule $77 \%$ du rendement frais et $87 \%$ du rendement en matière sèche. Une fois pris en compte la teneur en matière utile du lait, d'autres caractéristiques du lait ( $\mathrm{pH}$, variants de la caséine kappa) peuvent modifier le rendement fromager, mais de manière marginale.

\section{lait / taux protéique et butyreux / rendement fromager}

* Correspondence and reprints

Tel.: 33 (0)4 714564 14; fax: 33 (0)4 714564 13; e-mail: iverdier @ clermont.inra.fr 


\section{INTRODUCTION}

Cheesemaking is a process concentrating milk components, in particular fat and protein contents which are determinant factors of cheese yield [2], influencing the efficiency and profitability of cheesemaking [10]. Many authors have been interested in the predictive yield [3, 9, 12, 21, 23]. Cheesemakers have in recent years experienced cheese yield stagnation despite increasing protein contents, which have led them to question the cheesemaking value of milk proteins. Cheese yield is influenced by many factors including milk composition, milk preteatments, coagulant type, vat design, and cutting program $[2,11,16,18$, 32]. Caseins are concentrated in the curd during milk coagulation; their proportion in relation to total proteins can perceptibly fluctuate under the effect of genetic or physiological factors but apparently not proportionally to the level of protein content [7]. Other characteristics of milk can, however, facilitate protein solubilisation (plasmin proteolytic action), alter the rennet forming process (cell count, $\mathrm{pH}$, mineral content, urea content) or affect curd [33, 34], and so more or less influence cheese yield. Finally, milk preservation parameters (time, temperature) or technological failure can result in fat and protein losses during the cheesemaking process and therefore explain the stagnation in cheese yield.

The aim of this study was to analyze the relationship between the chemical composition of milk and the actual cheese yield according to a wide-ranging variation of milk fat and protein contents. In order to do this, animal and milk characteristics susceptible of affecting cheese yield were recorded from different controlled-condition cheesemaking experiments.

\section{MATERIALS AND METHODS}

The data used in this study resulted from eight experiments on the effect of breeding/ husbandry factors (genetic type and/or feed nature in particular) on the characteristics of ripened cheeses $[6,8,28,29,30$, unpublished results]. The cows, under experimental management conditions in these different experiments, differed in breed (Holstein, Montbéliarde, Tarentaise), lactation stage and feeding. Although all milks were partly skimmed (see next paragraph), the fat and protein content of milk varied greatly (Tab. I). In addition, the milks used for cheesemaking in some experiments contained different proportions of the B-variant of $\kappa$-casein, which is known to strongly influence milk clotting. The cows whose milk was used were all free of clinical mastitis at the time of the cheesemakings.

\subsection{Pilot plant}

In the eight experiments, the milk of the cows were transformed into Saint-Nectaire type cheese in an experimental cheese factory equipped with two 40-litre maximum capacity vats, making two cheeses $(1.8 \mathrm{~kg}$ each) per vat. The cheeses were produced from raw milk, partly skimmed so as to obtain a fat content/protein content ratio close to 1.15 , under controlled cheesemaking conditions. The milks used were collected at evening (seven experiments) or morning (one experiment) milkings. The evening milks were refrigerated and maintained at $4{ }^{\circ} \mathrm{C}$ until processing. The milks were first warmed up to $32{ }^{\circ} \mathrm{C}$ in the vats for about 15 minutes, then they were partly skimmed if necessary. The evening milks were enriched with $\mathrm{CaCl}_{2}\left(0.15 \mathrm{~g} \cdot \mathrm{kg}^{-1}\right)$ to make up for the reduction in colloidal calcium phosphate on chilling. All milks were inoculated (inoculation rate fluctuated from 0.9 to $1.0 \%$ according to the experiment) with a lyophilized mesophilic starter culture (Flora Danica Direct, Sochal, SaintÉtienne-de-Chomeil, France) reconstituted in sterile skimmed milk $\left(100 \mathrm{~g} \cdot \mathrm{L}^{-1}\right)$ then renneted at $32{ }^{\circ} \mathrm{C}$ with a $520 \mathrm{mg}$ active chymosin rennet (Gand-gassiot, Granday 
Table I. Characteristics of the milks used.

\begin{tabular}{|c|c|c|c|c|c|}
\hline & $n$ & Mean & $\begin{array}{l}\text { Standard } \\
\text { deviation }\end{array}$ & Min & $\operatorname{Max}$ \\
\hline Fat $\left(\mathrm{g} \cdot \mathrm{kg}^{-1}\right)$ & 189 & 34.8 & 2.4 & 29.2 & 44.2 \\
\hline Protein $\left(\mathrm{g} \cdot \mathrm{kg}^{-1}\right)$ & 189 & 32.2 & 2.6 & 25.9 & 40.5 \\
\hline Fat + protein $\left(\mathrm{g} \cdot \mathrm{kg}^{-1}\right)$ & 189 & 67.0 & 4.8 & 55.4 & 84.7 \\
\hline Urea $\left(\mathrm{g} \cdot \mathrm{kg}^{-1}\right)$ & 187 & 0.33 & 0.07 & 0.16 & 0.50 \\
\hline Calcium $\left(\mathrm{g} \cdot \mathrm{kg}^{-1}\right)$ & 169 & 1.28 & 0.10 & 1.10 & 1.54 \\
\hline Somatic cell $\left(1000 \cdot \mathrm{mL}^{-1}\right)$ & 184 & 175 & 126 & 13 & 590 \\
\hline $\mathrm{pH}$ & 187 & 6.68 & 0.05 & 6.52 & 6.80 \\
\hline Milk dry matter (\%) & 189 & 12.7 & 5.03 & 10.6 & 14.2 \\
\hline Whey dry matter $\left(\mathrm{g} \cdot \mathrm{kg}^{-1}\right)$ & 189 & 6.79 & 0.22 & 6.13 & 7.55 \\
\hline Dry matter of molded curd (\%) & 189 & 47.2 & 1.53 & 41.6 & 52.0 \\
\hline Dry matter of ripened cheese $(\%)$ & 166 & 54.4 & 1.97 & 48.8 & 60.4 \\
\hline \multicolumn{6}{|c|}{$\begin{array}{l}\text { Genetic variants of lactoprotein } \\
\text { (\% of B-allele with regards to all the existing alleles): }\end{array}$} \\
\hline$\alpha_{\mathrm{S} 1}$-casein & 189 & 91.7 & 8.4 & 67 & 100 \\
\hline$\beta$-casein & 189 & 7.2 & 10.2 & 0 & 42 \\
\hline$\kappa$-casein & 189 & 33.7 & 18.3 & 0 & 81 \\
\hline$\beta$-lactoglobulin & 189 & 53.6 & 10.8 & 36 & 79 \\
\hline \multicolumn{6}{|l|}{ Cheese yield ${ }^{1}$} \\
\hline Yf $\left(\mathrm{kg}\right.$ curd $\left.\cdot(100 \mathrm{~kg} \mathrm{milk})^{-1}\right)$ & 189 & 13.3 & 0.74 & 11.2 & 16.3 \\
\hline Ydm $\left(\mathrm{kg}\right.$ DM curd $\left.\cdot(100 \mathrm{~kg} \text { milk })^{-1}\right)$ & 189 & 6.26 & 0.46 & 5.01 & 7.91 \\
\hline $\operatorname{CRdm}(\%)$ & 189 & 51.8 & 2.22 & 45.7 & 60.5 \\
\hline
\end{tabular}

${ }^{1}$ Formula calculated with partly skimmed milk are defined in the text.

Laboratory, Beaune, France) at a rate of $35.3 \mathrm{~g}$ per $100 \mathrm{~kg}$ of milk. Clotting time was assessed visually. Twenty-five minutes after renneting, the curd was mechanically cut for $5 \mathrm{~min}$, then stirred for $40 \mathrm{~min}$ after extracting a third of the whey, which was replaced by the same volume of water. It was then left to drain in a pressing tray until it reached a $\mathrm{pH}$ close to 6.20. Two cheeses per vat were then formed in cloth molds and pressed until a pH of 5.30-5.40 was reached. The cheeses were then removed from the hoops and brined $\left(200 \mathrm{~g} \cdot \mathrm{L}^{-1} \mathrm{NaCl}\right)$ for $7 \mathrm{~h}$ at $10^{\circ} \mathrm{C}$. They were then placed in a ripening cellar for 8 weeks at $10-12{ }^{\circ} \mathrm{C}$ with a relative humidity of $97-98 \%$.

A total of 189 cheeses were produced. The cheesemaking technology in all the experiments was identical and controlled for the best in order to evaluate the effect of the production factors studied (breed, lactation stage, feed).

\subsection{Measurements}

Protein and fat contents (infra red method, Combifoss 5400, Foss Electric, Hillerod, Denmark), calcium content [15], urea content (dimethylamino-4-benzaldehyde (DMAB) method) as well as $\mathrm{pH}$, somatic cell count (Somacount, Bentley, Chaska, Minnesota 55318, USA), milk total bacterial count [1] and butyric acid bacteria spore count [4] were measured on a representative sample taken from each vat of cheese milk. 
At each cheesemaking, the weight of freshly molded curd was measured as well as the dry matter of milk, whey, molded curd and ripened cheese by desiccation at $103{ }^{\circ} \mathrm{C}$ for $24 \mathrm{~h}$ [14]. The fat and protein losses were only assessed by the dry matter of whey. The frequencies of the B-allele of $\beta$-lactoglobulin and $\alpha_{\mathrm{S} 1^{-}}, \beta$ - and $\kappa$-casein were computed for each cheese milk sample according to the individual genetic characteristics of the cows whose milk was used in any given batch. The genetic variants of lactoproteins were identified by isoelectric focussing of a milk sample [27].

Cheese yields were computed as follows: fresh yield (Yf) was computed by dividing the weight of fresh curd by the quantity of milk used for cheesemaking. Dry matter yield (Ydm) was computed by multiplying fresh yield by the dry matter (DM) value of the molded curd. The coefficient of dry matter recovery (CRdm) was computed by applying the following formula:

[(curd quantity $\times$ dry matter at

$\mathrm{CRdm}=$ molding $) /($ milk quantity $\times$ milk dry matter) $] \times 100$.

\subsection{Statistical analysis}

The data were processed by analysis of variance [26]. The variables introduced in this model were the rank number of the experiment, milk usable matter content (fat content + protein content), urea and calcium contents, milk pH, somatic cell count (divided into three groups: $<100000$ cells. $\mathrm{mL}^{-1}, 100000-200000$ cells $\cdot \mathrm{mL}^{-1}$ and $>200000$ cells $\cdot \mathrm{mL}^{-1}$ ) as well as the frequency of the B-allele of $\kappa$-casein. The allele frequency of other lactoproteins, such as the $B$ allele of $\beta$-lactoglobulin in particular, was not considered because of the very restricted variability of the latter frequency from one cheesemaking process to another.

\section{RESULTS AND DISCUSSION}

All the milks analyzed in this study had somatic cell counts below 600000 cells $\cdot \mathrm{mL}^{-1}$ (and below 200000 cells $\cdot \mathrm{mL}^{-1}$ in $71 \%$ of the cases), a total bacterial flora below $50000 \mathrm{UFC} \cdot \mathrm{mL}^{-1}$ and butyric acid bacteria spore counts below 500 spores $\cdot \mathrm{L}^{-1}$.

The different cheese yield expressions were as follows $(\mathrm{FPC}=$ fat content + protein content):

$$
\begin{aligned}
\mathrm{Yf}=\quad & 4.243+0.135 \mathrm{FPC} \pm 0.350 \\
& R^{2}=0.77 \quad n=189 \\
\mathrm{Ydm}= & 0.191+0.091 \mathrm{FPC} \pm 0.165 \\
& R^{2}=0.87 \quad n=189
\end{aligned}
$$

$\mathrm{CRdm}=27.98+0.356 \mathrm{FPC} \pm 1.440$

$$
R^{2}=0.59 n=189 \text {. }
$$

Fresh yield was significantly correlated to the fat and protein contents (equation (1)). In the model, this variable (FPC) alone explained $77 \%$ of fresh yield variability. The correlation with DM yield was even stronger (equation (2), 87\% of the explained variability). With such a great variation of milk fat and protein contents $\left(55-85 \mathrm{~g} \cdot \mathrm{kg}^{-1}\right)$, the relation between FPC and DM yield was linear (Fig. 1), as already observed by Colin et al. [5], in soft paste cheesemaking experiments. The dry matter recovery coefficient (CRdm) was higher when milk fat and protein content were higher (equation (3), +3.6 points per 100 for a $10 \mathrm{~g} \cdot \mathrm{kg}^{-1}$ increase in fat and protein contents). Indeed, the fat and protein losses in whey (as assessed from

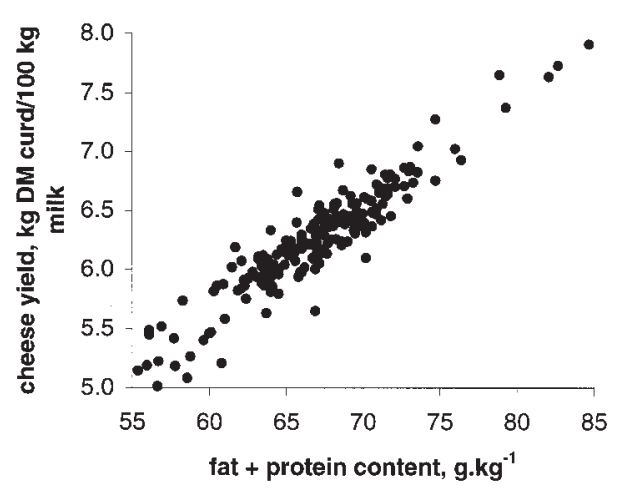

Figure 1. Relationship between cheese yield and fat + protein content $(n=189)$. 
whey DM) varied little: these losses only increased by $0.1 \mathrm{~g} \cdot \mathrm{kg}^{-1}$ as milk fat and protein content increased by $10 \mathrm{~g} \cdot \mathrm{kg}^{-1}$. In relative terms, fat and protein losses in whey were lower in the milks characterized by high fat and protein contents.

The consideration of certain additional variables allows to appreciably improve the prediction yield. With the two yields (Yf and $\mathrm{Ydm}$ ) and the dry matter recovery coefficient $(\mathrm{CRdm})$ studied, the experimental effect was significant $(P<0.01)$ but quantitatively low: with the same milk fat and protein contents, the difference in fresh yield between extreme values of the experiment was $0.35 \mathrm{~kg} \cdot(100 \mathrm{~kg} \text { milk })^{-1}$, that is $2.6 \%$ and the difference in DM yield was $0.24 \mathrm{~kg} \mathrm{DM} \cdot(100 \mathrm{~kg} \text { milk })^{-1}$, that is $3.8 \%$. This experimental effect was perceptibly reduced when other milk characteristics were considered but it remains significant. The "experimental" factor was therefore retained for future analyses.

With regards to fresh yield with the same fat and protein content, both $\mathrm{pH}$ and the proportion of the $\mathrm{B}$ variant of $\kappa$-casein played a predominant role: an increase in $0.1 \mathrm{pH}$ units induced a cheese yield decrease of $0.28 \mathrm{~kg} \cdot(100 \mathrm{~kg} \mathrm{milk})^{-1}(P<0.01)$ and a $10 \%$ increase in the frequency of the $\kappa$-casein $\mathrm{B}$ allele induced a $0.05 \mathrm{~kg} \cdot(100 \mathrm{~kg} \text { milk })^{-1}$ increase $(P<0.01)$. The beneficial effect of the $\mathrm{B}$ variant of $\kappa$-casein on milk coagulation properties is well known [13, 24]. Its effect on cheese yield has been studied less $[31,32]$ although it is classically positive [19], because of DM loss being limited to whey [20] and the higher casein/protein ratio $[7,25]$. In our study, however, the whey DM content was not found to be dependent on the frequency of the $\kappa$-casein $B$ allele. The dry matter of the curd obtained was higher when the contents of protein and fat in the milk were higher too $(+0.18$ points per 100 to each additional gram of fat and protein content). But with the same milk fat and protein contents, the water content of the curd was higher when $\mathrm{pH}$ was lower. This finding was a surprise insofar as it has been classically accepted that curd syneresis is quicker at low $\mathrm{pH}$ [34]. This was probably linked to the cheesemaking process chosen, performed with a standard quantity of rennet and during which the curd cutting was carried out at a set interval following renneting ( $25 \mathrm{~min}$ ) regardless of the curd state. Under these conditions, with acid milks, it is likely that curd cutting was done too late, with the coarser grain retaining more water. Consequently, once the effect of fat and protein content was taken into account, only the proportion of the $\mathrm{B}$ variant of $\kappa$-casein had a positive and significant $(P<0.05)$ but moderate effect on DM yield: a $10 \%$ increase in the $\kappa$-casein $\mathrm{B}$ allele frequency induced a $0.01 \mathrm{~kg} \cdot(100 \mathrm{~kg} \text { milk })^{-1}$ increase in dry matter.

After considering the fat and protein contents, milk calcium content never had a significant effect on cheese yield, nor did milk urea content. Calcium plays a major role in improving cheese yield [17, 22]. However, in our study the variability of that factor was relatively low ( $8 \%$ variation coefficient) and the best part of that variability $(58 \%)$ was linked to the trial effect and to the protein content (calcium concentration increased by approximately $0.02 \mathrm{~g} \cdot \mathrm{kg}^{-1}$ for each additional point of protein content, $P<0.001$ ). The milk somatic cell count had no significant effect on the various expressions of yield, on the contrary to what was reported by Lucey and Kelly [18] whenever somatic cell counts exceeded $100000 \cdot \mathrm{mL}^{-1}$.

The dry matter losses between molding and the end of ripening were not linked to the milk fat and protein contents, so that the dry extract of ripened cheese was higher when the milk was richer in fat and protein $(+0.16$ points per 100 for each additional gram of fat and protein contents, $P<0.001)$.

\section{CONCLUSION}

This study confirmed that milk fat and protein contents predominantly influence cheese yield. It showed that during pressed, 
uncooked paste cheesemaking, using high hygienic quality milks (cows free from clinical mastitis) swiftly processed under well mastered manufacturing techniques, that there is a linear relationship between FPC and cheese yield, even when fat and protein contents are very high because of the lactation stage or animal genetic characteristics. Once the effects of fat and protein contents have been taken into consideration, other milk parameters $(\mathrm{pH}, \kappa$-casein variant) may have a significant but quantitatively marginal effect on cheese yield.

\section{REFERENCES}

[1] AFNOR, Microbiology analysis of food products. Routine method for microorganism counting. Count technique for colonies obtained at $30{ }^{\circ} \mathrm{C}$, Standard NF V 08-051, Association Française de Normalisation, Paris La Défense, France, 1992.

[2] Banks J.M., Banks W., Muir D.D., Wilson A.G., Cheese yield: composition does matter, Dairy Ind. Int. 46 (1981) 15-22.

[3] Banks J.M., Muir D.D., Tamine A.Y., Equations for estimation of the efficiency of Chedda cheese production, Dairy Ind. Int. 49 (1984) 14-17.

[4] Cerf O., Bergère J.L., La numération des spores de Clostridium et son application au lait et aux produits laitiers. II. Numération des différents groupes de Clostridium, Lait 48 (1968) 501-519.

[5] Colin O., Laurent F., Vignon B., Variations du rendement fromager en pâte molle. Relations avec la composition du lait et les paramètres de la coagulation, Lait 72 (1992) 307-319.

[6] Coulon J.B., Verdier I., Pradel P., Effet du mode de présentation du même fourrage (foin ou herbe pâturée) sur les caractéristiques de fromages de Saint-Nectaire affinés, Lait 76 (1996) 479-486.

[7] Coulon J.B., Hurtaud C., Rémond B., Vérité R., Factors contributing to variation in the proportion of casein in cows' milk true protein: a review of recent INRA experiments, J. Dairy Res. 65 (1998) 375-387.

[8] Coulon J.B., Verdier-Metz I., Pradel P., Almena M., Effect of lactation stage on the cheesemaking properties of milk and the quality of SaintNectaire type cheese, J. Dairy Res. 65 (1998) 295-305.

[9] Emmons D.B., Ernstrom C.A., Lacroix C., Verret P., Predictive formulas for yield of cheese from composition of milk a review, J. Dairy Sci. 73 (1990) 1365-1394.
[10] Emmons D.B., Economic importance of cheese yield, in: International Dairy Federation Special Issue 9301, Factors affecting the yield of cheese, International Dairy Fed., Brussels, Belgium, 1993, pp. 10-11.

[11] Fenelon M.A., Guinee T.P., The effect of milk fat on Cheddar cheese yield and its prediction using modifications of the Van Slyke cheese yield formula, J. Dairy Sci. 82 (1999) 2287-2299.

[12] Gilles J., Lawrence R.C., The yield of cheese, N.Z. J. Dairy Sci. Technol. 20 (1985) 205-214.

[13] Grosclaude F., Le polymorphisme génétique des principales lactoprotéines bovines. Relations avec la quantité, la composition et les aptitudes fromagères du lait, INRA Prod. Anim. 1 (1988) 5-17.

[14] IDF, Determination of the total solids contents: Gravimetric (Cheese and processed cheese), Standard 4A, International Dairy Federation, Brussels, Belgium, 1982.

[15] IDF, Determination of calcium content: Flame atomic absorption spectrometric method (Milk and dried milk), Standard 154, International Dairy Federation, Brussels, Belgium, 1992.

[16] Lawrence R.C., Processing conditions, in: International Dairy Federation Special Issue 9301, Factors affecting the yield of cheese, International Dairy Fed., Brussels, Belgium, 1993, pp. 64-78.

[17] Lucey J.A., Fox P.F., Importance of calcium and phosphate in cheese manufacture: a review, J. Dairy Sci. 76 (1993) 1714-1724.

[18] Lucey J., Kelly J., Cheese yield, J. Soc. Dairy Technol. 47 (1994) 1-14.

[19] Mariani P., Pecorari M., Il ruolo delle varianti genetiche della $\kappa$-caseina nella produzione de formaggio, Sci. Tec. Latt. Casearia 42 (1991) 255-285.

[20] Mariani P., Losi G., Russo V., Castagnetti G.B. Grazia L., Morini D., Fossa E., Prove di caseificazione con latte caratterizzato dalle varianti A e B della K-caseina nella produzione del formaggio Parmigiano-Reggiano, Sci. Tec. Latt. Casearia 27 (1976) 208-227.

[21] Maubois J.L., Ricordeau G., Mocquot G., Étude des rendements en fromagerie de Camembert et de Saint-Paulin, Lait 50 (1970) 351-373.

[22] Metzger L.E., Barbano D.M., Rudan M.A., Kindstedt P.S., Effect of milk preacidification on low fat Mozarella cheese. I. Composition and yield, J. Dairy Sci. 83 (2000) 648-658.

[23] Mocquot G., Ricordeau G., Auriol P., Estimation du rendement en fromage Gruyère de Comté en fonction de la richesse du lait de chaudière, Ann. Zootech. 12 (1963) 53-66.

[24] Rahali V., Ménard J.L., Influence des variants génétiques de la $\beta$-lactoglobuline et de la $\kappa$-caséine sur la composition du lait et son aptitude fromagère, Lait 71 (1991) 275-297. 
[25] Reichardt W., Gernand E., Schuler D., Zusammenhänge zwischen dem Eiweißgehalt der Kuhmilch und der Caseinzahl. 1. Mitteilung: Übersicht über die Einflußfaktoren auf die Caseinzahl, Arch. Tierz. 38 (1995) 263-276.

[26] SAS Institute Inc., SAS User's Guide: Statistics, SAS Institute Inc., Cary, NC, USA, 1987.

[27] Seibert B., Erhardt G., Senft B., Procedure for simultaneous phenotyping of genetic variants in cow's milk by isoelectric focusing, Anim. Blood Groups Biochem. Genet. 16 (1985) 183-191.

[28] Verdier I., Coulon J.B., Pradel P., Berdagué J.L., Effect of forage type and cow breed on the characteristics of matured Saint-Nectaire cheeses, Lait 75 (1995) 523-533.

[29] Verdier-Metz I., Coulon J.B., Pradel P., Viallon C., Berdagué J.L., Effect of forage conservation (hay or silage) and cow breed on the clotting properties of milks and on the characteristics of ripened cheeses, J. Dairy Res. 65 (1998) 9-21.

[30] Verdier-Metz I., Coulon J.B., Pradel P., Viallon C., Albouy H., Berdagué J.L., Effect of botanical composition of hay and casein genetic variants on the chemical and sensory characteristics of ripened Saint-Nectaire type cheeses, Lait 80 (2000) 361-370.

[31] Walsh C.D., Guinée T.P., Harrington D., Mehra R., Murphy J., Connolly J.F., Fitzgerald R.J., Cheedar cheesemaking and rennet coagulation characteristics of bovine milks containing $\kappa$-casein AA or BB genetic variants, Milschwissenschaft 50 (1995) 492-496.

[32] Walsh C.D., Guinée T.P., Harrington D., Mehra R., Murphy J., Fitzgerald R.J., Cheesemaking, compositional and functional characteristics of low-moisture part-skim Mozarella cheese from bovine milks containing $\kappa$-casein $\mathrm{AA}, \mathrm{AB}$ or BB genetic variants, J. Dairy Res. 65 (1998) 307-315.

[33] Walstra P., The syneresis of curd, in: Fox P.F (Ed.), Chapman et Hall, Cheese: chemistry, physics and microbiology, 2-6 Boundary Row, London SE1 8 HN, UK, 1993, pp. 141-191.

[34] Weber F., L'égouttage du coagulum, in: Eck A (Ed.), Le fromage, Technique et Documentation, Lavoisier, Paris, 1987, pp. 22-36. 